Aleksandra Szwagrzyk-Dalasińska*

\section{Melpomena w krótkich spodenkach}

DOI: http://dx.doi.org/10.12775/LC.2017.057

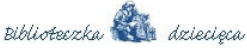

TEATR I DRAMAT

\section{DLA DZIECI I MŁODZIEŻY}

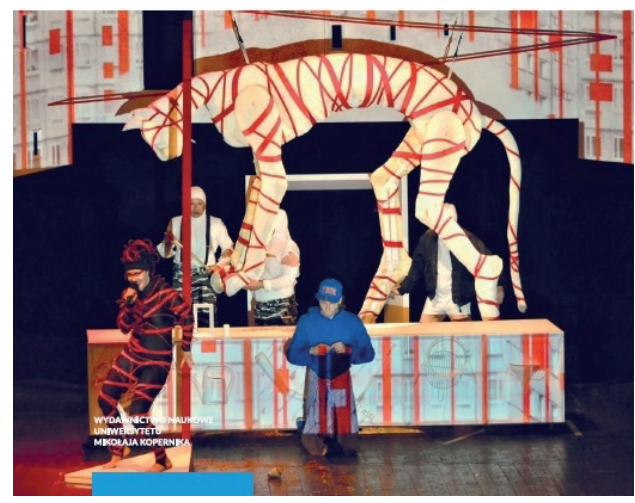

$\mathrm{T}$

om z roku 2016 zatytułowany Teatr idramat dla dzieci i mtodzieży jest pracą zbiorową pod redakcją dwójki toruńskich badaczy literatury - Marzenny Wiśniewskiej oraz Macieja Wróblewskiego. Ten ostatni jest redaktorem serii „Biblioteczka dziecięca”, a recenzowana publikacja stano-

\footnotetext{
* Absolwentka filologii polskiej W Instytucie Literatury Polskiej Uniwersytetu Mikołaja Kopernika w Toruniu, obecnie doktorantka na Wydziale Filologicznym UMK. Zajmuje się literaturą dla dzieci i młodzieży. E-mail: aleksandra.szwagrzyk@o2.pl
}

wi jej drugą odsłonę (pierwsza to tom Sztuka dziecięca i mtodzieżowa a nowe media $\mathrm{z}$ roku 2015). Pozycja wydana została przez Wydawnictwo Naukowe Uniwersytetu Mikołaja Kopernika.

Redaktorzy książki to pracownicy Wydziału Filologicznego UMK. Maciej Wróblewski jest badaczem literatury oraz kultury dziecięcej i młodzieżowej, autorem publikacji „Czytanie przyszłości”. Polska fantastyka naukowa dla młodego czytelnika (2009), a także organizatorem cyklu konferencji „Biblioteczka Niedorosłych”, które odbywają się regularnie od roku 2014 w Instytucie Literatury Polskiej UMK. Ich pokłosiem jest między innymi seria o literaturze dla młodych. Marzenna Wiśniewska zajmuje się naukowo badaniami nad teatrem, była także kierownikiem literackim Teatru „Baj Pomorski” w Toruniu.

Autorzy publikujący w omawianej pracy zbiorowej stawiają sobie za cel odnalezienie odpowiedzi na pytania dotyczące nowych rozwiązań we współczesnym teatrze dla młodych odbiorców. Teatr i dramat dla dzieci i młodzieży to publikacja, który łączy dwie perspektywy - stricte literaturoznawczą (prace dotyczące dramatów dla niedorosłych odbiorców) oraz teatrologiczną (artykuły, w których analizuje się wybrane inscenizacje). Taka dwoistość perspektywy sprawia, że zaprezentowane i omawiane teksty kultury odkrywają przed czytelnikiem nowe oblicza i sposoby interpretacji.

Przygotowanie tomu w całości poświęconego zagadnieniom związanym z dramatem oraz teatrem dla młodych pokazuje, że inscenizacje tego typu nie są mniej istotne od tych, które przeznaczone są dla widzów dorosłych.

Publikację podzielono na trzy części, poprzedzone wstępem redaktorów, którzy dokonują rekonesansu propozycji dramatyczno-teatralnych dla młodego widza, a także prac naukowych, które na ten temat 
powstały. Podkreślają dynamikę rozwoju poszukiwań artystycznych w takim typie teatru, zaznaczają, że jest on nierozerwalnie związany nie tylko z kulturą żywego słowa, ale też na przykład z nowymi mediami. Pierwsza część zatytułowana Wokół funkcji teatru składa się z czterech tekstów. Ewa Tomaszewska w artykule Odnaleźć siebie. O teatrze dla dzieci i mtodzieży pisze o kilku projektach teatralno-artystycznych adresowanych dla dzieci, ich analiza pokazuje, jaka jest istota teatru, który ma służyć zainspirowaniu młodych ludzi do kształtowania siebie ${ }^{1}$. Z kolei Beata Gromadzka jest autorką szkicu dotyczącego potrzeby pielęgnowania mitu $\mathrm{w}$ teatrze dla dzieci. Analizuje sztukę $W$ beczce chowany Roberta Jarosza, omawia wyniki ankiet przeprowadzonych wśród gimnazjalistów, podkreśla rolę tego typu przekazuw kształtowaniu tożsamości młodych ludzi.

Trzeci artykuł - Zapomniany język? $O$ roli wypowiedzi teatralnej $w$ dyskursie tożsamościowym. $\mathrm{Na}$ materialne projektu „Laboratorium teatralne” autorstwa Jerzego Kaniewskiego, to próba odnalezienia odpowiedzi na pytanie, jaki teatr warto włączyć w zakres kulturowych doświadczeń młodych ludzi. Pierwszą część tomu zamyka artykuł Karoliny Papiorkowskiej-Dymet, piszącej o teatrze terapeutycznym Inki Dowlasz. Badaczka pokazuje, że teatr to także środek wychowawczy i dydaktyczny w bardzo nowoczesnym wydaniu. Można tutaj dostrzec nawiązania do badań dotyczących inscenizowania zabaw na podstawie tekstów dla młodzieży².

Druga partia artykułów, zebrana w rozdziale Wokót repertuaru, zostaje otwar-

\footnotetext{
1 Na marginesie warto wspomnieć, że teatr to także w pewnym sensie każda szkolna lekcja, zob. L. Barszcz, Lekcja jako zdarzenie artystyczne, „Polonistyka” 1997, nr 1.

2 Zob. Inscenizowanie zabaw na podstawie literatury dziecięcej, red. J. Cybulska i in., Warszawa 1991, J. Dybczyńska, Terapia przez teatr, „Polonistyka” 2008, nr 5 .
}

ta szkicem Marzenny Wiśniewskiej o tematach „nie dla dzieci” w teatrze dla dzieci, w którym toruńska badaczka omawia kwestię tematów tabu w repertuarze dedykowanym niedorosłym. Kolejny z autorów Jacek Mikołajczyk, podejmuje się refleksji na temat dzieci w musicalach - tłumaczy, że najmłodszym odbiorcom często pokazuje się te same treści, co dorosłym, ale w złagodzonej formie. Mirosława Pindór oraz Karol Suszczyński referują zagadnienia związane $\mathrm{z}$ teatrem lalkowym. Obydwoje badacze patrzą na ten typ sztuki jako na coś ożywczego, łączącego klasykę oraz eksperyment ${ }^{3}$. Z kolei Bartłomiej Oleszek zajął się teatrem radiowym z perspektywy antropologii, ale i nowych mediów.

W ostatniej części tomu poświęconego twórczości scenicznej dla dzieci znajdują się trzy teksty oscylujące wokól tematu związków teatru i literatury. Ryszard Waksmund traktuje o dziecku oraz teatrze w świetle wspomnień i pamiętników, Jolanta Ługowska natomiast o teatrze jako temacie literackim. Badaczy łączy skupienie na doświadczeniu niedorosłych odbiorców, na których teatr oddziałuje nie bezpośrednio, ale przez literaturę. Publikację zamyka praca Violetty Wróblewskiej o dramacie dla młodych, który ma swoją inspirację w folklorze.

Niezwykle istotne jest to, że autorzy publikujący w omawianym tomie skupiali się nie tylko na samej sztuce teatralnej, ale także na dramacie. Kiedy w internetową wyszukiwarkę wpisuje się frazę „dramat i teatr dla dzieci”, pojawiają się głównie artykuły na temat przedstawień teatralnych, recenzje oraz repertuary teatrów dla niedorosłych jeszcze odbiorców. Zdawać się może, że dziecięcy adresaci interesują się tylko sztu-

\footnotetext{
3 Por. R. Nowicka, Zaczarowany świat teatru lalek, „Wychowanie w Przedszkolu” 1999, nr 6.
} 
ką teatralną, a sam dramat odkładają na bok i traktują go zupełnie marginalnie.

Temat teatru dla dzieci jest często pomijany $\mathrm{w}$ publikacjach teatrologicznych, świadczyć może o tym chociażby nieobecność tego zagadnienia $\mathrm{w}$ publikacji Widowisko - teatr - dramat. Skrypt dla studentów kulturoznawstwa $a^{4}$ W akademickim podręczniku dla studentów kierunków humanistycznych całkowicie przemilczany zostaje dramat oraz teatr dla niedorosłych odbiorców. Lukę tę zapełnia jednak dwutomowa publikacja Dziecko i teatr $w$ przestrzeni kultury (tomy Teatr w świecie, Świat $w$ teatrze) pod redakcją Marty Karasińskiej oraz Grzegorza Leszczyńskiego wydana przez Centrum Sztuki Dziecka w Poznaniu. Pojawiają się tutaj, podobnie jak w tomie pod redakcją Wiśniewskiej i Wróblewskiego, rozważania dotyczące funkcjonowania oraz istoty teatru dla niedorosłych w XXI wiekuod postmodernizmu w sztukach teatralnych dla młodych po zagadnienia teatru w szkole czy teatru dla osób niepełnosprawnych.

Podejście redaktorów jest również bardzo podobne, jak pisze we wstępie do Świata $w$ teatrze Grzegorz Leszczyński: „Kultura i teatr są tym samym. Teatr z samej swej istoty »żywi się《 narracją, a więc, poza sytuacjami, gdy ma ona charakter czysto niewerbalny, literaturą. Z kolei teatralizacja, obecna znacznie powszechniej poza teatrem, niż w samym jego obrębie, organizuje ludzkie doświadczenia, także doświadczenia kulturalne"s. Potwierdzeniem tego, że teatralizacja obecna jest w codziennym życiu, są chociażby teksty Ryszarda Waksmunda o związkach pamiętnikarstwa $\mathrm{z}$ teatrem czy Jolanty Ługowskiej o tematy-

\footnotetext{
${ }^{4}$ Widowisko - teatr - dramat. Skrypt dla studentów kulturoznawstwa, red. E. Wąchocka, Katowice 2010.

5 G. Leszczyński, Wstęp, [w:] Dziecko i teatr w przestrzeni kultury, t. 1, Teatr w świecie, red. M. Karasińska, G. Leszczyński, Poznań 2007, s. 15.
}

zowaniu teatru w powieściach Małgorzaty Musierowicz.

Redaktorzy toruńskiego tomu mocno podkreślają związki teatru z literaturą, zagadnieniu temu poświęcają jedną z trzech części swojej książki zbiorowej. Wiśniewska i Wróblewski dostrzegają także rolę performatywności sztuki teatralnej - wstęp do tomu tytułują Teatra dla matego i mtodego widza. Zarys problematyki, nawiązują więc do publikacji Dariusza Kosińskiego Teatra polskie. Historie 6 , który pojęcie „teatra” wykorzystuje do opisywania tekstów dramatycznych zmieniających życie odbiorców.

Należałoby zatem podjąć refleksję nad tym, czym jest dziecięce doświadczenie i jak zostaje ono zaprezentowane $\mathrm{w}$ dramacie, a potem w sztuce teatralnej. W czym tkwi sukces dziecięcych festiwali teatralnych czy po prostu teatrów, które wystawiają sztuki dla niedorosłych? Istotne jest tutaj weryfikowanie w praktyce analityczno-interpretacyjnej procedur właściwych różnym konceptualizacjom kategorii dziecka i dzieciństwa. Zapomnieć nie można też o interpretacji kategorii dziecięcości w sztuce. Po lekturze tomu Teatr $i$ dramat dla dzieci i młodzieży na myśl przychodzi wniosek, że istnieją pewne kryteria, które pozwalają na badanie nowych paradygmatów teatru skonfrontowanych $\mathrm{z}$ kategorią dziecięcego doświadczenia. Widać to wyraźnie już w pierwszym artykule - autorstwa Ewy Tomaszewskiej (Odnaleźć siebie. O teatrze dla dzieci i młodziézy).

Po pierwsze, należy zwrócić uwagę na to, jak zmienne były wyobrażenia dziecka oraz dzieciństwa w dziejach kultury europejskiej. Perspektywę dzieciństwa rozpatrywać należy w sposób teoretyczny, zwrócić uwagę na chociażby kategorie „mdłości

\footnotetext{
6 D. Kosiński, Teatra polskie. Historie, Warszawa 2010.
} 
dzieciństwa” czy „cierpkości młodości”. Kluczowe dla odczytania najnowszego dramatopisarstwa byłoby też zwrócenie uwagi na podejście Korczakowskie (dzieci to ludzie), które Hanna Kirchner opisuje następującymi słowami „Przemienił dzieciństwo w człowieczeństwo, z niedojrzałości uczynił inność, niższość wywyższał przez pionierski trud literackiego poznania"

Odmienne spojrzenie na dramat może przynieść też wiedza $\mathrm{z}$ lat sześćdziesiątych - kiedy to Philippe Ariès mówi o nim na nowo'. Istotne będzie też wykorzystanie ustaleń Marty Karasińskiej ${ }^{10}$ - dyskursywizacja $^{11}$ pojęcia dzieciństwa oraz proces polegający na jego upodmiotowieniu ${ }^{12}$.

\footnotetext{
7 "Każdy człowiek czuje w sobie tę mdłość dzieciństwa, dla zdrowego rozsądku obmierzłą, tę cierpkość młodości, która karmi się czułymi przedmiotami, a dla człowieka roztropnego jest jeno grubiańską rozpusta", Ph. Ariès, Historia dzieciństwa. Dziecko i rodzina w dawnych czasach, przeł. M. Ochab, Gdańsk 1995, s. 135.

8 H. Kirchner, Miejsce Korczaka w literaturze, [w:] Janusz Korczak. Życie i dzieło, Warszawa 1982, s. 55.

9 "Ujmuje on [Philippe'a Ariès] [...] dzieciństwo jako semantycznie zmieniający się proces, przyjmujący różnorodne znaczenia w zależności od kultury i momentu historycznego. Można powiedzieć, że nie ma »dzieciństwa« ani »dziecka« w znaczeniu uniwersalnym. Znaczenia przypisywane tym pojęciom zmieniały się wraz ze zmiana wartości, poglądów i stosunków społecznych, stając się "papierkiem lakmusowym« epoki", M. Obrębska, Semantyka dzieciństwa: od nieobecności do odrębności, https://repozytorium. amu.edu.pl/ bitstream/10593/4366/1/2-obrebska.pdf (dostęp: 12.07.2017).
}

10 Zob. M. Karasińska, Dziecko w świecie post-teatru, [w:] Sztuka dla dziecka jako forma komunikacji społecznej, t. 1, G. Leszczyński, Poznań 2009, M. Karasińska, Na scenie tekstu, [w:] Porwani przez przenośnie, red. E. Balcerzan i A. Kwiatkowska, Poznań 2007, M. Karasińska, Teatr czy literatura? (O literaturoznawczej teorii teatru), „Przestrzenie Teorii” 2003, nr 2.

11 W tym przypadku pojęcie "dyskurs", zgodnie z definicją słownikową oznacza "dyskusję na tematy naukowe", http://sjp.pwn.pl/sjp/dyskurs;2555763. html (dostęp: 06.07.2017).

12 Dyskursywność stanowi także istotny element badań tożsamościowych. Stuart Hall zaznacza, iż dyskursywność stanowi cechę dystynktywną tożsamości (S. Hall, Who Needs 'Identity'?, ed. by S. Hall, P. du Gay, Questions of Culture Identity, London 1996, p. 4). Rodzi się ona z tych materiałów, które odbiorca może samodzielnie zdobyć - wtedy też kształtuje się jego
Ta pierwsza grupa wyznaczników byłaby grupą teoretyczną, scharakteryzowaną przez autorów monografii w pierwszej jej części pt. Wokól funkcji teatru.

Niezwykle istotne są ustalenia Jerzego Kaniewskiego, dotyczące roli wypowiedzi teatralnej $\mathrm{w}$ dyskursie tożsamościowym, które potwierdzają, że we współczesnych badaniach nad teatrem odbiorcy do czynienia mają z dyskursywizacją tego, co teatralne oraz dziecięce. Jak pisze Teun van Dijk: „Choć wielu badaczy dyskursu skupia się szczególnie na języku mówionym, na wypowiedzi, wydaje się, że w obręb pojęcia dyskursu warto włączyć też teksty pisane. Istnieje wiele podobieństw między sposobami mówienia i pisania, jakie dane osoby stosują w celu wyrażania swoich przekonan’”13, dlatego też Jerzy Kaniewski podkreśla, że badać należy nie tylko sam dramat (czyli tekst pisany), ale i przedstawienie (czyli $\mathrm{w}$ pewnym sensie tekst mówiony - a w zasadzie pisany poddany interpretacji aktorskiej i wygłoszony). Na potrzeby artykułu analizuje działania grupy „Laboratorium Teatralne", do której należą dydaktycy Instytutu Filologii Polskiej UAM. Zadaniem programu było wspieranie metodyków w nowoczesnych formach kształcenia nauczycieli - wykorzystując narzędzia teatralne.

Drugą perspektywą, która widoczna jest w tomie jest perspektywa „doświadczeniowa" o charakterze edukacyjno-artystycznym; do zbadania związków dzieciństwa i teatralnego dyskursu wykorzystuje między innymi kategorię zabawy - postrzeganej jako najważniejsza właściwość wieku nie-

tożsamość, jest to proces, który nigdy się nie kończy. Rozwój człowieka polega zdaniem badacza na pytaniu samego siebie o ważkie kwestie kulturowe, językowe, związane z rzeczywistością, ale istotą tych pytań nie jest odpowiedź, ale sam proces ich zadawania.

13 T.A. van Dijk, Badania nad dyskursem, [w:] Dyskurs jako struktura i proces, red. idem, przeł. G. Grochowski, Warszawa 2001, s. 11. 
dorosłego. Ponadto w tym miejscu autorzy szkiców zamieszczonych w rozdziałach Wokót repertuaru oraz Wokót relacji teatru i literatury, podjęli refleksję nad egzystencjalnymi doświadczeniami dzieci oraz młodzieży, które stają się potem materiałem na dramat (tutaj jako niezwykle istotny jawi się tekst Ryszarda Waksmunda na temat dziecka i teatru w świetle wspomnień i pamiętników).

W tej kategorii mieściłby się także folklor dziecięcy czy badania na temat struktury tekstu dla dzieci - analogia do zabawy (zagadnienie to szczególowo opisuje w swoim tekście toruńska badaczka folkloru i kultury dziecięcej - Violetta Wróblewska). W tej części znajdują się także inne badania nad dzieckiem w na przykład radio (Bartłomiej Oleszek w swoim szkicu przedstawia historię teatru radiowego dla dzieci i młodzieży) czy związkami dziecka i kultury popularnej (Jacek Mikołajczyk omawia tę kwestię na przykładzie funkcjonowania musicalu we współczesnej kulturze). Doświadczeniowość to również zbadanie tego, co stereotypowe w dziecięcym dramacie oraz tego, co poddane jest tabu, zagadnienie zostało omówione przez Marzennę Wiśniewską $\mathrm{w}$ artykule o tabu $\mathrm{w}$ teatrze dziecięcym oraz młodzieżowym.

Omawiane problemy łączą się także z pytaniami oraz analizami związanymi $\mathrm{z}$ zagadnieniami edukacyjno-artystycznymi. W tym miejscu omówieniu poddano formy działań teatralnych oraz parateatralnych - grupy impro (ta kwestia jest jedynie zasygnalizowana $\mathrm{w}$ wybranych artykułach) czy lalkowe teatry dla dzieci. Artykuł na ten temat przygotował Karol Suszczyński, który pisze o repertuarze odpowiednim dla lalkowego teatru dla młodych odbiorców zastanawia się nad tym, jaka problematyka najbliższa jest dzieciom oraz młodzieży, które oglądają teatry lalkowe. Mirosława Pindór analizuje, jakie zadania narodowe, patriotyczne niesie ze sobą teatr lalkowy odwołuje się tutaj do kategorii doświadczenia oraz tożsamości.

Tom pod redakcją Marzenny Wiśniewskiej oraz Macieja Wróblewskiego stanowi omówienie dwu fundamentalnych kwestii związanych $\mathrm{z}$ teatrem i dramatem dla niedorosłych odbiorców - pojawia się część dotycząca perspektywy teoretycznej oraz część dotycząca perspektywy doświadczeniowej o charakterze edukacyjno-artystycznym. Perspektywy te lączą w sobie polskie festiwale teatrów (dla) dzieci i młodzieży: poznańskie Biennale Sztuki dla Dziecka, Małe Warszawskie Spotkania Teatralne, Ogólnopolski Przegląd Teatrów Dziecięcych i Młodzieżowych „Dziatwa”, Ogólnopolski Festiwal Ekspresji Dziecięcej i Młodzieżowej czy akcja Sztuka Szuka Malucha.

Gdyby redaktorzy zdecydowali się na kontynuowanie serii, to warto byłoby pochylić się także nad kwestią festiwali ${ }^{14}$. Interesującym dopełnieniem publikacji mogłaby być również część dotycząca teatrów nieprofesjonalnych dla dzieci oraz młodzieży. Janusz Gajda zaznacza, że akty ekspresji twórczej dzieci mają niezwykle ważkie znaczenie w kształtowaniu ich osobowości, a sama sztuka dziecka oraz ta o charakterze amatorskim jest jedną z najbardziej wartościowych form uczestnictwa w kulturze ${ }^{15}$.

Badaczy zainteresowanych zagadnieniem teatru i dramatu dla młodych odbiorców odesłać można do dostępnej on-line publikacji z roku 2016 autorstwa Ireny JajteLewkowicz pt. Teatr dziecięcy i młodzieżo-

14 Redaktor książki Marzenna Wiśniewska jest także redaktorem tomu Teatr wśród mediów, w którym omawiane są kwestie związane z festiwalami (Teatr wśród mediów, red. A. Duda, M. Wiśniewska, B. Oleszek, Toruń 2015).

15 J. Gajda, Antropologia kulturowa. Wprowadzenie do wiedzy o kulturze, Kraków 2008, s. 48. 
wy we wspótczesnej praktyce kulturowej ${ }^{16}$. Przechadzka po tematach i lekturze. Autorka dokonuje niezwykle bogatej kwerendy dotyczącej omawianej problematyki, zamieszcza bibliografię $\mathrm{z}$ literaturą przedmiotu, w której zbiera tytuły kilkudziesięciu tomów dotyczących dramaturgii i teatru dla młodych ludzi.

Opisywane w książce pod redakcją Marzeny Wiśniewskiej oraz Macieja Wróblewskiego kategorie („doświadczeniowa” oraz teoretyczna) służą zaprezentowaniu jednej nadrzędnej kategorii - tego, jak dziecięce doświadczenie zostaje przekazane przez dorosłego w tekście dla niedorosłego. Pojawia się napięcie na linii autor-tekst-czytelnik. I to napięcie jest właśnie kluczem do zrozumienia dramatopisarstwa dla dzieci, co niezwykle trafnie uwypuklono w omawianej książce zbiorowej.

Tom Teatr i dramat dla dzieci i mtodzieży polecić można każdemu badaczowi literatury dla młodzieży, ale także teatrologom, antropologom kultury i literatury oraz kulturoznawcom. Redaktorom oraz autorom udało się wejść $\mathrm{w}$ dialog z twórcami ra-

portu (badacze teatru z UAM w Poznaniu) Młodzi i teatr. Szanse i bariery na przykładzie Wielkopolski z roku 2013, którzy piszą: „Sztuka teatralna potrzebuje kompleksowych, interdyscyplinarnych badań zdarzeń teatralnych, w których uwzględniane byłoby samo dzieło, jego struktura estetyczna i społeczno-kulturowa, ale także publiczność (widzowie) - ich zaangażowanie, kompetencje, praktyki i sposoby rozmawiania o teatrze" 17 .

Warto podkreślić także, że omawiana książka to jedna $\mathrm{z}$ niewielu publikacji zbiorowych dotykająca tematu teatru dla dzieci w tak nowoczesny sposób, nie podważający jednak roli tradycji $\mathrm{w}$ badaniach nad dramatem i teatrem. Łączy się tutaj praxis $\mathrm{z}$ teorią - od omawiania konkretnych sztuk teatralnych po teoretyczne rozważania na temat roli teatru $\mathrm{w}$ rzeczywistości nowych mediów.

Teatr i dramat dla dzieci i młodzieży, red. M. Wiśniewska, M. Wróblewski, Wydawnictwo Naukowe Uniwersytetu Mikołaja Kopernika w Toruniu, Toruń 2016, ss. 231.

16 I. Jajte-Lewkowicz, Teatr dziecięcy i młodzieżowy we współczesnej praktyce kulturowej, http://www. boklodz.pl/images/BOK_CENTRALA/Wydarzenia/ Dziatwa_2016/dziatwa2016_wydawnictwo.pdf (dostęp: 07.07.2017). Publikacja ta była przygotowana jako element biuletynu promującego 37. Ogólnopolski Przegląd Teatrów Dziecięcych i Młodzieżowych „Dziatwa” 2016.
17 B. Mateja-Jaworska i in., Młodzi i teatr. Szansy i bariery na przykładzie Wielkopolski, publikacja internetowa na stronie Regionalnego Obserwatorium Kultury w Katowicach, http://www.regionalneobserwato riumkultury.pl (dostęp: 06.07.2017). 